\title{
Sexual Assault in the Department of Obstetrics and Gynaecology of the Bamako's 5th Municipality Medical Center
}

\author{
Bambara Moussa*, Coulibaly Karim, Diallo Abdoul Aziz, Ouattara Adama, Zampaligré Idrissa \\ Gynécologue, Bobo-Dioulasso, Burkina Faso \\ Email: *mousbambara@yahoo.fr
}

How to cite this paper: Moussa, B., Karim, C., Aziz, D.A., Adama, O. and Idrissa, Z. (2016) Sexual Assault in the Department of Obstetrics and Gynaecology of the Bamako's 5th Municipality Medical Center. Open Journal of Obstetrics and Gynecology, 6, 654660.

http://dx.doi.org/10.4236/ojog.2016.611082

Received: September 15, 2016

Accepted: October 22, 2016

Published: October 25, 2016

Copyright $\odot 2016$ by authors and Scientific Research Publishing Inc. This work is licensed under the Creative Commons Attribution International License (CC BY 4.0)

http://creativecommons.org/licenses/by/4.0/

\begin{abstract}
Background: The authors report cases of sexual assault reported to the obstetrics and gynecology department of the Bamako's 5th municipality medical center during a prospective study of eight months from 1st January to 31st August 31st, 2012. Results: Twenty-one cases of assault were reported out of a total of 13,482 consultations, representing a frequency of $0 \%, 15 \%$. Most victims were represented by students and accounted $43 \%$ of the study population. In $76 \%$ of cases the victims knew their assailant. The type of sexual contact was genito-genital vaginal penetration in $67 \%$ of cases and the condom was used in only one case. The average time before consultation was 3 days. The preventive ARV treatment was administered in $24 \%$ of cases and emergency contraception in $43 \%$ of cases. Conclusion: Sexual assault is common in Bamako. The reality is probably underestimated because many cases are not reported. The victims are mostly children and adolescents. The risk of transmission of STIs and HIV is very high during the sexual assault. Education and awareness of the population are essential for early consultation. Training of health workers to care for victims of sexual assault is needed.
\end{abstract}

\section{Keywords}

Sexual Assault, Support, Victim, Bamako, Mali

\section{Introduction}

Sexual violence affects every year millions of people worldwide. It undermines the honor of the person and his family and may have repercussions in long term.

In 1997, WHO [1] estimated that at least $20 \%$ of women worldwide had suffered during their lives of physical or sexual abuse. 
In 2004, sexual offenses accounted for $9 \%$ of all overall crime in France [2]. In the US, approximately 32,000 pregnancies occur each year due to sexual assault [3].

In Mali, the frequency of sexual assault was $0.12 \%$ according to a study conducted by Drama B. in 2002 [4]. The consequences of these assaults on victims could result in trauma, gynecological and psychological injuries. The purpose of this study was to investigate cases of sexual assault seen in the Bamako's $5^{\text {th }}$ municipality medical center in the purpose to contribute to better management.

\section{Material and Method}

The study was conducted in the obstetrics and gynecology's department of the Bamako's $5^{\text {th }}$ municipality medical center. It was a descriptive prospective study over a period of eight month from January 2012 to August 2012, on cases of sexual assault seen and managed in the obstetrics and gynecology's department during the study period. The Data were collected from clinical records and consulting records using a survey sheet.

The variables of interest were: age, marital status, occupation, origin, circumstances of the sexual assault, the lesions observed, the profile and the number of aggressor, additional examinations and care. Entry and data analysis were performed using the EpiInfo Version 6.0 software

\section{Results}

\subsection{Epidemiology}

\section{Frequency}

During the study period, we received 21 cases of sexual assault among 13482 patients who came for consultation, representing a frequency of $0.15 \%$

\section{Demographics}

Age: The mean age of our patients was 18 years with extremes of 7 and 29 years. The distribution of sexual assault by age group is as follows:

- 7 - 9 years: 2 cases $(9.5 \%)$.

- 10 - 19 years: 13 cases (62\%).

- $\geq 20$ years: 6 cas $(28.5 \%)$.

Marital status: The single women accounted for $86 \%$ of the study population while married women representing $14 \%$.

Profession: out of a total of 21 patients, students accounted for $43 \%$. The distribution of victims by occupation is as follows:

- Students: 9 cas (43\%).

- House maids: 7 cases (33\%).

- Street vendors: 5 cases (24\%).

Origin: the majority of our patients $(71 \%)$ came from Bamako's $5^{\text {th }}$ municipality and the remaining $29 \%$ from elsewhere.

The profile and the number of aggressor

The age of the aggressors: The mean age was 26 years with extremes of 17 and 33 years. In 12 cases there was only one assailant and in other cases there were two and 
more assailants.

Table 1 below shows the distribution of patients by number of aggressors.

\subsection{Circumstances of Sexual Assault}

\section{The time of sexual assault}

According to the time, the distribution of victims of aggression was:

- 08:00 - 18:00 Hours: 10 cases (48\%).

- 18:00 - 00:00 Hours: 7 cases (33\%).

- 00:00 - 08:00: 4 cases (19\%).

Fifty two percent of sexual assaults occurred after sunset while $48 \%$ occurred in the day.

\section{The place of sexual assault}

Fifty two percent of sexual assaults occurred at homes while $29 \%$ occurred in an uninhabited area.

Table 2 below shows the distribution of victims by place of aggression.

\section{The type of sexual contact}

In thirteen cases (61.9\% of the study population), it was vaginal penetration while in 5 cases (23.8\% of the study population) it was other types of contact. The distribution of victims by sexual contact types is as follows:

- Genito-genital penetration: 13 cases (61.9\%).

- Simple touch: 5 cases (23.8\%).

- Others (oral, anal and instrumental penetration): 3 cases (14.3\%).

The relationship between the victim and the aggressor.

The perpetrators were of the family circle in $33 \%$ of cases, Known by the victims in $43 \%$ of cases and unknown in $24 \%$ of cases.

Table 1. Distribution of victims according to the number of aggressors.

\begin{tabular}{ccc}
\hline Number of aggressor & Number & $\%$ \\
\hline 1 & 12 & 57 \\
2 & 4 & 19 \\
$\geq 3$ & 5 & 24 \\
Total & 21 & 100 \\
\hline
\end{tabular}

Table 2. Distribution of victims depending on venue of the sexual assault.

\begin{tabular}{ccc}
\hline Venue & Number & Percentage \\
\hline Inhabited places & 11 & 52 \\
Non habited places & 6 & 29 \\
Public places $^{(\mathrm{a})}$ & 4 & 19 \\
Total & 21 & 100 \\
\hline
\end{tabular}

(a) = bus station, school, leisure center, Garden. 


\section{The use of means of protection}

The condom was used as protection in only 1 case.

\subsection{Clinical Data}

\section{The average time before consultation}

The distribution of victims according to the consultation period was as follows:

- Within $1^{\text {st }}$ day: 5 cases $(23.8 \%)$.

- After $1^{\text {st }}$ day - $7^{\text {th }}$ day: 12 cases $(57.2 \%)$.

- $8^{\text {th }}$ day $-15^{\text {th }}$ day: 4 cases $(19 \%)$.

The mean time of consultation was 8 days. Twelve patients (57\% of the study population) was seen within the $1^{\text {st }}$ to $7^{\text {th }}$ day.

\section{The pattern of injuries}

Physical examination allowed to observe bodily harm to such abrasions in $14 \%$ of cases. Lesions of bruising type at the vulva in 9 cases and a sore in one case. Lesions of tears at the hymen were present in 6 cases $(28.5 \%)$.

\subsection{Para Clinical Aspects}

All cases of sexual assault seen in the department, after the clinical examination, the following sample's laboratory investigation were requested:

- the search of sperm in the genital tract: The presence of sperm was found in one case.

- the blood samples for serology (HIV, Hepatitis B, Syphilis).

- the immunological pregnancy test: it was performed in 19 cases with negative results. However it was not performed in 2 cases because the victims were 7 and 8 year old and were not in the puberty period.

\subsection{Management}

- Psychological support was provided to all victims by a psychologist.

- Antibiotics per os and local care based on clinical the findings were provided to 14 cases. Tetanus prophylaxis and immunization were given to these patients.

- Post coital contraception was given to all victim of childbearing age seen within a period of 72 hours after the assault.

- HIV infection prophylaxis was provided to 7 victims after they had a negative serology ( 5 case within 24 hours, 2 after 48 hours).

- Prevention of hepatitis B infection through vaccination was provided to 6 patients after they had a negative serology. Twelve cases could not benefit, due to lack of financial means.

\subsection{Follow up of the Victims}

Medical follow up was recommended for victims with a first appointment at 1 month and a second appointment at 3 months.

For the first appointment, they benefited a medical consultation and immunological 
pregnancy test for women of childbearing age. Fifteen were seen and the outcome was unremarkable.

For the third month 7 victimes were seen, with one case of HIV-positive status.

\section{Discussion}

\subsection{Epidemiology}

The frequency of sexual assault found in our study was $0.15 \%$. It is close to that reported by Drama [4] in 2008 in the same department which was $0.12 \%$. Our frequency is lower than those reported by Faye Dieme [5] in Senegal and Nguessan [6] in Ivory Coast, which were $0.4 \%$ and $0.68 \%$ respectively. Mbassa [7] in a school survey in Cameroon reported a higher frequency of $15.9 \%$. Most studies in the United States [8] and South Africa highlighted high frequencies up to $15 \%$. Furthermore, we see that it is in situations of instability and disorder (curfew, armed conflicts, disasters) that the number of sexual abuse increases dramatically [9]. In its report on health and the war in Congo-Brazzaville, Health and Human Rights [9] had counted between May and December 1999, a total de1600 rape cases. Sexual assault remains a taboo subject in Sub Sahara Africa. Shame, worthlessness of the person and his family, psychological immaturity and fear of reprisals from the perpetrator are the main reasons of silence [10]. The mean age in our series was de 18 years. It is close to that reported by Ayadi [11] in Tunisia which was 18,6 years and greater than those reported by Some Burkina [12], Mbassa in Cameroon [7] and Faye Dieme in Senegal [5], who were respectively 7 years, 11.6 and 15 years. Victims of sexual abuse are especially children and adolescents in the African series. Children and adolescents accounted for $62 \%$ in our series, $72.5 \%$ in the series of Mbassa in Cameroon [7], 90.2\% for Buambo-Bamanga in Congo Brazzaville [13] and 95\% for Faye Dieme in Senegal [5]. The precarious economic conditions (housekeepers, vendors), the low level of education, promiscuity, celibacy are factors that expose sexual abuse.

For the profile of aggressors, the mean age ( 25 years) was similar to that of Mbassa [7] (25.3 years). He was in the family circle or known to the victims in $76 \%$ of cases and unknown in $24 \%$ of cases. This similarity has been reported by other authors [5] [7] [13].

\subsection{The Circumstances of Sexual Assault}

In our study, most of the attacks were carried out at night, $52 \%$ of cases. The same observation was noted by Some in Burkina, 57\% of cases [12] and Nguessan in Ivory Coast, $63.6 \%$ of cases [6].

The type of sexual contact in our series was vaginal penetration in $67 \%$ of cases. This trend has been noted by several authors: Mbaye Magatte in Senegal, 74\% of cases [14], in Burkina, $78.6 \%$ of cases [15], Buambo-Bamanga in Congo, $80.4 \%$ of cases [13] and Mbassa in Cameroon, $83.2 \%$ of cases [7]. In our study, the condom was used only once. In the light of various studies on sexual assault [4]-[9] [12] [14], which showed that condom use is rare with a high risk of exposure of the victim to STIs and HIV. In the 
management of sexual assault it is imperative to prevent STIs and HIV, especially when the victim is seen earlier. For the relationship between the victim and the aggressor, most studies show that the perpetrator was known and familiar to the victim. This link was reported in $76 \%$ of cases in our study, $57.9 \%$ of cases for Buamba-Bamanga in Congo Brazzaville [2], 76\% of cases for Lankoande in Burkina Faso [10], 70\% for Faye Dieme in Senegal [5] and 92.4\% for Mbassa in Cameroon [7].

\subsection{Clinical Aspects}

Our average period before consultation of 8 days is similar to that in Burkina which is 8.2 days [12] and lower than what Mbaye reported in Senegal which is 4 weeks [14]. This long delay is due to the disco; fort of families to discuss issues that affect family honor, especially when the perpetrator is a relative of the victim. often preferred $<$ washing dirty linen within family $>$. It is when, it appears obvious disagreements that the family brings the problem to the health and judicial authorities. The lesions at the hymen were identified in $28.5 \%$ of cases. Traore in Mali has found those lesions in $13.48 \%$ of cases [15], while Faye Dieme reported those lesions in 54.5\% of cases [5].

\subsection{Para Clinical Aspects}

The results of various blood tests were negative in the first investigations. Search for sperm came back positive in one case. The high costs of investigations (about 34 US \$) were in the charge of the family pending a hypothetical repayment by aggressor after a trial in court or a settlement.

\subsection{Therapeutic Aspects}

We provided oral antibiotics and local care in 14 cases. The morning after pill was administered to all victims of childbearing age. Prophylaxis for HIV infection was administered in 7 cases. The morning after pill, antibiotic therapy and prophylaxis for HIV infection were performed in other studies [5] [12] [14] for victims seen earlier for consultation.

\subsection{Follow up of the Victims}

In our study, the 3rd month follow-up, we reviewed 7 victims, and the findings were unremarkable in 6 case. In 1 case the HIV test was positive. Many cases of HIV/AIDS have been reported after sexual assault in South Africa, Cameroon and Congo-Brazzaville [7] [13] [16]. After sexual assault especially within 24 hours, the practitioner needs to initiate prophylactic treatment of HIV infection for $1 \mathrm{month}$, as it is difficult to take samples from the aggressors.

\section{Conclusion}

Sexual assault is common in Bamako. The reality is probably underestimated because many cases are not reported. The victims are mostly children and adolescents. The risk of transmission of STIs and HIV is very high during the sexual assault. Education and 
awareness of the population are essential for early consultation. Training of health workers to care for victims of sexual assault is needed.

\section{References}

[1] Juillet, O.M.S. (1997) La violence contre les femmes. Genève, 3-6.

[2] Lejeune, J. (2011) Caractéristiques médico-légales de l'examen gynécologique normal comparé à celui des victimes d'agression sexuelle. Thèse Med, Nancy.

[3] Holmes, et al. (1996) Rape Related Pregnancy Estimates and Descriptive Characteristics from a National Sample of Women. American Journal of Obstetrics \& Gynecology, 175, 320-325. http://dx.doi.org/10.1016/S0002-9378(96)70141-2

[4] Drame, B. (2002) Les abus sexuels au centre de santé de référence de la commune Vdu district de Bamako. Thèse, Med, Bamako.

[5] Dieme, F., Traore, A.L., Gueye, S.K.M., Moreira, P., Diouf, A. and Moreau, J.C. (2008) Profil épidémioclinique et prise en charge des victimes d'abus sexuel à la clinique gynécologique et obstétricale du CHU de Dakar. Journal de Gynécologie Obstétrique et Biologie de la Reproduction, 37, 358-364. http://dx.doi.org/10.1016/j.jgyn.2007.11.002

[6] N'Guessan, K., Bokassa, M., Boni, S., Kone, N. and Bohoussou, K. (2004) Les violences sexuelles chez la femme, une réalité africaine. Med d Afr Noire, 51, 306-310.

[7] Mbassa, M. and Ngoh, F. (1999) Réconciliation et/ou médiation comme voies de recours en cas d'abus sexuels sur mineurs au Cameroun. Med Trop, 59, 161-164.

[8] Jewkes, R., Sen, P. and Garcia-Moreno, C. (2002) Sexual Violence. Word Report on Violence and Health. Word Health Organization, Geneva, 213-239.

[9] Health and Human Rights. Health and War in Congo-Brazzaville. Lancet, 356, 1762. http://dx.doi.org/10.1016/S0140-6736(00)03217-7

[10] Lankoande, J., Ouango, J.G., Sondo, B., Kone, B. and Soudre, R. (1994) Les agressions sexuelles: A propos de 30 observations au Centre Hospitalier National Yalgado Ouédraogo. Résumé des rapports et communications, $1^{\text {er }}$ journée de gynécologie et d'obstétrique de Bamako, 17-18-19 Février 1994. Livre des résumés.

[11] Ayadi, A., Hammami, Z., Khemakhem, Z., Fourati, H., Ben Issa, M., Bardaa, S. and Maatoug, S. (2005) Les agressions sexuelles dans la région de Sfax (Tunisie). Journal of Medicine, 48, 506-513.

[12] Some, A.D., Ouattara, S., Sioho, N., Dembele, A., Da, E.G., Bazié, A.J., Bambara, M. and Dao, B. (2009) Agressions sexuelles à Bobo-Dioulasso, Burkina Faso. Science et Technique, Sciences de la Santé, 32.

[13] Buamba-Bamanga, S.F., Oyere Moke, P., Gnekoumou, A.L., Nkihouabonga, G., Ekoundzola, J.R., et al. (2005) Violences sexuelles à Brazzaville. Cahiers d’études et de Recherches Francophones/Santé, 15, 31-35.

[14] Mbaye, M., Gueye, M., Ndiaye, G., Diarra, M., Dieng, O., et al. (2013) Abus Sexuels Dans Une zone reculée du sud Sénégal: épidémiologie et prise en charge. Tunisie Med, 91, 499-504.

[15] Traore, Y., Moukoro, N., Teguete, I., Djire, M.Y., Diallo, A. and Dolo, A. (2010) Aspects Cliniques et médico-légaux des agressions sexuelles au CHU Gabriel Toure. Mali Med, 27-30.

[16] Marsaud, O. (2001) Les viols, plaies des écoles Sud-Africaines. OMS, 222-230. 
Submit or recommend next manuscript to SCIRP and we will provide best service for you:

Accepting pre-submission inquiries through Email, Facebook, LinkedIn, Twitter, etc. A wide selection of journals (inclusive of 9 subjects, more than 200 journals)

Providing 24-hour high-quality service

User-friendly online submission system

Fair and swift peer-review system

Efficient typesetting and proofreading procedure

Display of the result of downloads and visits, as well as the number of cited articles

Maximum dissemination of your research work

Submit your manuscript at: http://papersubmission.scirp.org/

Or contact ojog@scirp.org 